\title{
Land Acquisitions and Rural Poverty: Unveiling Ambiguities in the District of Caia (Mozambique)
}

\author{
Elena Ianni ${ }^{1}$ \\ ${ }^{1}$ Department of civil and environmental engineering, University of Trento, Trento, Italy \\ Correspondence: Elena Ianni, Department of civil and environmental engineering, University of Trento, Trento, \\ Italy. Tel: 39-0461-282-685. E-mail: elena.ianni@ing.unitn.it
}

Received: May 10, 2012 Accepted: June 20, 2012 Online Published: August 20, 2012

doi:10.5539/enrr.v2n3p52

URL: http://dx.doi.org/10.5539/enrr.v2n3p52

\begin{abstract}
In the fight against rural poverty, the government of Mozambique fosters land acquisitions as a rapid economic development catalyzer assuming that investors increase the productivity of marginal and unused lands and negotiate long-term benefits with local communities abiding to legal prescriptions. This study aimed at unveiling the ambiguities of these policy assumptions in the district of Caia.

Questionnaires were used to investigate families' risk perception and marginal lands use in local communities, while in-depth interviews with traditional community authorities addressed land access mechanisms, legal knowledge and information flows. This study showed that what is superficially considered by the government unused and marginal lands is in fact the land that allows people to sustain their complex livelihoods. Conversely, there is evidence that communities are largely unprepared to undertake a negotiation process with land investors.
\end{abstract}

Keywords: food security, land access, land investments, land-use planning, risk-management strategies, rural livelihoods, subsistence economy

\section{Introduction}

In Mozambique, as in many African countries, land acquisitions and forest exploitation leases are emerging as a means to rapidly achieve an alleged rural development under the assumption that they play an important role in catalyzing economic development facilitating infrastructure expansion and creating employment. Mozambican Government stated that only $9 \%$ of the country's 36 million hectare of arable land is currently cultivated and that there is the opportunity of extending production to an additional 41.2 million hectare of marginal land, currently fallow (Nhantumbo \& Salomao, 2009). In Mozambique, two suppositions in particular underpin the argument that land and forest deals are "development catalyzers". The first one is that investors acquire the use of marginal or unused lands that in this way increase their productivity and utility. The second is that the award of the concessionary rights to investors applying for land is subject to a mandatory consultation and negotiation process with the local community and this is supposed to facilitate a win-win solution for local groups and investors. Many studies have shown that most of the land that is considered "remaining suitable land" for investments is not vacant, but actually already under use or claim, often by the local communities (Kugelman \& Levenstein, 2009; Smaller \& Mann, 2009). These studies argue that large scale acquisitions imperil small scale farmers' food security (Food and Agriculture Organization, 2009) and access to the resources on which they depend, not just land, but also water, wood and grazing (Haralambous et al., 2009). Moreover, it has been shown that there is a great and worrying distance between state laws and practice (Taylor \& Bending, 2009); the outcome of the consultation process is generally defined as unsatisfactory (Haralambous et al., 2009).

This paper explores the two assumptions in the district of Caia, located along the Zambezi River in Central Mozambique. The situation in the district is paradigmatic. The government has recently endorsed actions to relocate people from the isolated rural areas towards the neighborhoods of the urban centers. These actions have been described by the government as a policy to maximize the population safety and the access to water, schools and markets while minimizing investments. A recent governmental analysis (Governo do Distrito de Caia, 2006) claimed that the dispersion of settlements in the "wide" territory is the main cause of rural poverty and the main obstacle to development since it impedes capillary access to water and social facilities. On the other hand, contacts between government officers in charge of agricultural matters and investors have been established but very few contracts have been made available to the public or to non-governmental organizations. Moving people 
from the forested interior sparked accusations of facilitating the permeation of great land investors to these marginal and wide areas. Two basic research questions were tackled in the district of Caia:

1. Is the land of the rural hamlets dispersed in the inner part of the district 'underutilized', 'uncultivated' or 'available' as claimed by the government?

2. Is community consultation between land investors and local communities in place and effective in the interior part of the district?

In order to answer the first question, families' livelihood strategies in the rural areas of the district were described. In order to answer to the second question, land access mechanisms were explored with the traditional authorities through in-depth interviews.

\section{The Land Law in Mozambique}

In recent times focus on land transactions has impressively increased in academic research, in non-governmental organizations bulletins and in development agencies reports (Taylor \& Bending, 2009; Hallam, 2009; Robertson \& Pinstrup-Andersen, 2010). Cotula et al. (2009), in the most thorough review so far jointly published by IIED, FAO and IFAD, analysed land-based investments over five years in five African sub-Saharan countries and found that allocations total some 2 million hectares. A recent report issued by International Food Policy Research Institute estimates that since 2006, 15 to 20 million hectares of land were traded in negotiations or transactions in some 50 deals, mainly in Africa (von Braun \& Meinzen-Dick, 2009).

The Mozambican Constitution, written in 1990, allows all forms of private property but land is specifically excluded. The key clause states that 'Land is the property of the State and cannot be sold or alienated in any other form, nor can it be mortgaged'. During the 1990s, the government became increasingly aware of the growing proliferation of land use conflicts. It also became aware of the fact that such a climate was not favorable for investments in the agricultural sector, either by local communities or by private commercial interests. Based on the 1990 Constitution, in September 1995 the National Land Policy was approved. The central declaration of intent of the land policy was to "safeguard the diverse rights of the Mozambican people over the land and other natural resources, while promoting new investment and the sustainable and equitable use of these resources".

The Land Law, approved in 1997, recognizes the de facto occupation by those occupying land according to customary norms and practices. Traditional land management systems continue to be the principal means by which the rural poor obtain access to land: customary tenure to this day accounts for 90 percent of land tenure rights. The law also recognizes that land may not be sold or alienated but it can be leased for the purpose of "use and fruition" (direito de uso e aproveitamento, DUAT). The Land Law foresees that DUATs are granted on a 50 -year state leasehold, renewable for additional 50 years. Several procedural aspects are detailed in the law: concessions are subject to an agreement with the community that occupies the land under DUAT and to the approval by the district administrator. The agreement process includes mandatory meetings involving the community, the district administrator and neighboring communities, and a process of participatory delimitation of the area of the concession.

\section{The District of Caia}

The district of Caia, Province of Sofala, lies in the lower tract of the Zambesi river basin. The population of the district is concentrated along the main communication corridor (i.e. the national road Beira-Sena along which the towns of Caia and Sena are located). In recent years, infrastructure has been developed and upgraded. The railway line connecting Beira to the coal fields of Moatize and to Malawi was restored, the colonial bridge in Sena was renewed, and a new bridge in Caia over Zambezi River was built. Thanks to the infrastructural improvements, along with the introduction of electricity, the city of Caia increased in population from 39,153 in 1997 to 55,010 in 2007 with an increment of $40.5 \%$. Sena and Caia have progressively assumed the shape and functions of rural towns (Diamantini et al., 2011) because urban living functions coexist alongside rural ways of life. Instead, the interior part of the district still maintains a distinct rural character, and basic infrastructure roads, schools and water wells-lack, or do not provide adequate services (Figure 1). 


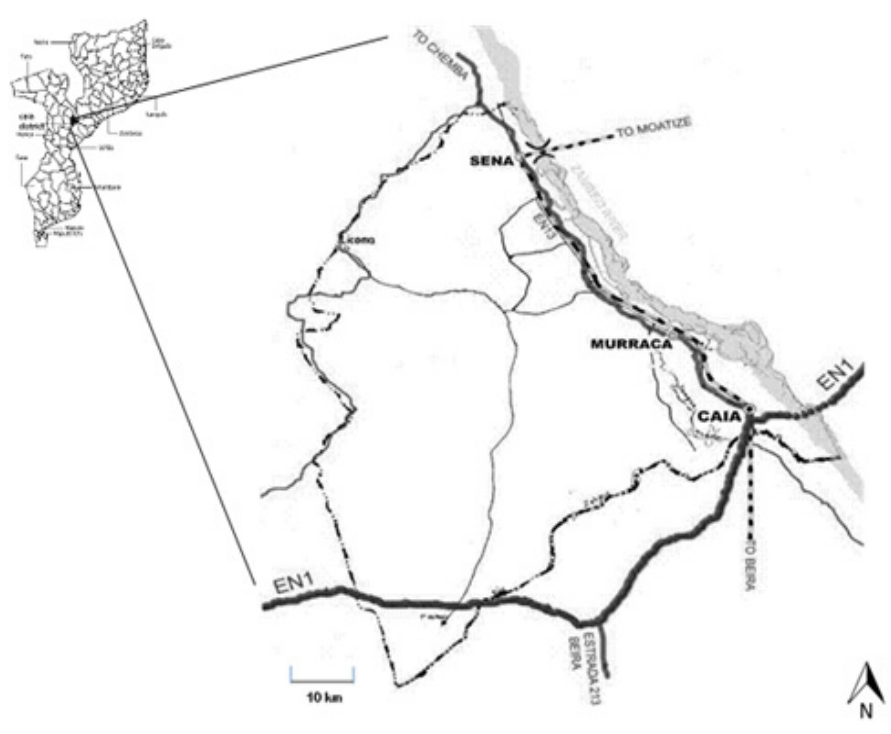

Figure 1. The district of Caia, Central Mozambique. The main communication corridor of the district is the national road along which the towns of Caia and Sena are located

\subsection{Geographical Definition}

The study area is included in the "Zambezian and Mopane Woodlands" ecoregion that extends throughout the lower-lying areas in the eastern portion of southern Africa. This ecoregion is characterized by the dominance of the tree Colophospermum mopane (Caesalpiniaceae), which is the sole canopy species throughout much of its range. Annual average rainfall generally ranges from $450 \mathrm{~mm}$ to $710 \mathrm{~mm}$. The higher elevations in the south may receive up to $1,000 \mathrm{~mm}$, with most precipitation falling between November and April. Temperatures vary between $-4^{\circ} \mathrm{C}$ and $46^{\circ} \mathrm{C}$, with a mean annual temperature range of $18^{\circ} \mathrm{C}$ to $24^{\circ} \mathrm{C}$. The morphology is generally flat or gently undulating along the floors of the major river valleys, with average elevations ranging from $200 \mathrm{~m}$ to $600 \mathrm{~m}$. This ecoregion is one of the most important areas for vertebrate diversity in southern Africa, particularly for mammals. The biota and associated natural processes have remained largely intact as a result of the extensive and well-maintained system of national parks and reserves. However, the Zambezi Valley portion of the ecoregion in Mozambique suffered a great loss of biodiversity during the civil war as soldiers and their families hunted many mammals due to famine. The dry deciduous forest that covers the majority of the district of Caia is defined by the local people as mato, distinguishing it from floresta, fragments of high canopy woodlands.

\subsection{Sena Communities}

Sena people of Caia, as western Bantu people according to the definition of Samson (1974), use to concentrate their dwellings and disperse their economic activities over a wide zone of exploitation. This is due to ecological conditions: firstly, the inland plateaux is characterized by large expanses of relatively uniform land and a sufficient variety of resources is rarely contained in small configurations. Secondly, finding a constant water supply source is a general issue. The main activity for families is agriculture and, as in most African cultures, women are responsible for the agricultural work. The villages in the rural areas of the district are characterized by dispersed settlements, the muzi, dotting the landscape. In a muzi the huts are arranged in a conventional semi or full circle around the courtyard. The central hut belongs to the chief's wife (the first) and the others are arranged on either side, according to their status. Each wife is entitled a house, with separate houses provided to the older boys and girls. Traditionally huts are sculptured out of the ground or weaved from locally grown thatch and wood. The administrative division of the Caia district is based on regulados, which are traditional units based on chieftainships. In the rural areas traditional authorities dominate: Regulo, Saphanda and M'fumo, in hierarchical order of descending importance.

In 2006, the regional government drafted a strategic development plan for the district. Limited agricultural production, insufficient drinking water sources, periodic floods and inadequate social infrastructure were identified as the main constraints. On the other hand, the presence of abundant water sources, high biodiversity in the forests, and soil fertility were described as the main strengths. On the basis of geographical and 
socio-economic criteria, the plan divided the Caia district into four areas (Figure 2):

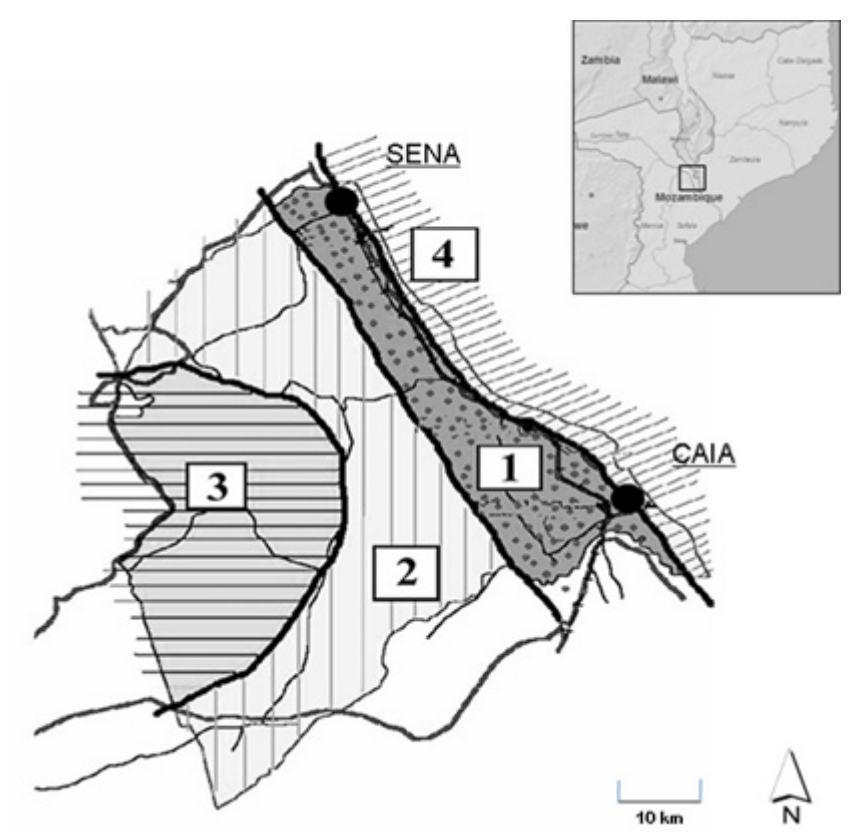

Figure 2. The division of the district of Caia according to the land use plan

Sub-region 1 - Area characterized by high population density;

Sub-region 2 - Area characterized by low population density and great agriculture potential;

Sub-region 3 -Area characterized by high forest density; and

Sub-region 4 - Lowlands subject to Zambesi river floods.

The government identified sub-region 1 as economically developed, sub-region 2 as a cluster of problematic communities, and sub-region 3 as a cluster of poverty. In the aftermath of the 2007 Zambesi River flooding, the government started a program to relocate the population from the sub-region 4 to areas of lower risk (sub-region 1) in villages named reasentamentos. The rationale and expected outcome was that the Zambesi River fertile floodplain should become unsettled. Also, the government recently endorsed actions to relocate people from the isolated rural areas of sub-regions 2 and 3 to the urban area of sub-region 1 .

\section{Methods}

In order to answer the research questions, information was gathered through quantitative and qualitative methods.

Questionnaires were used to investigate families' risk perception and marginal lands use in local communities, while in-depth interviews with traditional community authorities addressed land access mechanisms, legal knowledge and information flows. The sample included families and authorities in subregions 2 and 3 and in the extreme parts of subregion 1. Since the sample intended to encompass the families that inhabit the rural areas of the district, a random strategy, influenced in part by accessibility, was adopted. A map of the surveyed area was not available at survey time. During our field trips for the interviews, we mapped with GPS the rural trails to the villages.

\subsection{The Questionnaire to the Families}

The sample of the survey included 72 people: $75 \%$ male and $25 \%$ female. The age of the interviewees ranged between 18 and 84 years, with the median at 38 years. Thirteen individuals ( 10 of them women) were not able to specify their age. All interviews were conducted in Chisena (indigenous) language. If the interviewee was able to speak Portuguese, open questions were discussed without translation.

Questions were formally organized according to specific themes: 
1. Food production (information on family organization, agricultural yields and non agricultural activities that complement family livelihoods);

2. Food consumption (information on daily food intake and access to natural resources);

3. Food access (information on the type and amount of exchanges with the towns to acquire goods and commercialize the production );

4. Adaptive capacity of the families (information on the occurrence of agricultural calamities and strategies put in place by the families to cope with crisis);

5. Farmers' relationships with the land (information on spiritual values and land attachment).

The structure of the questionnaire is shown in Table 1.

The questionnaire presented both closed and open-ended questions. The form of the questionnaire was thoroughly reviewed by persons with years of work with Sena culture and tested with farmers to ensure the highest level of clarity.

Table 1. Framework of the questionnaire

\begin{tabular}{ll}
\hline & Indicators \\
\hline Food production & Families organization \\
& Agricultural yields \\
& Non agricultural activities \\
& Daily food intake \\
Food consumption & Access to natural resources \\
& Acquiring goods and commercializing the production \\
Food access & Life costs \\
& Agricultural crisis \\
Adaptive capacity & Strategies to cope with risk \\
Link with the land & Farmers' connections with land and forest \\
\hline
\end{tabular}

Families were surveyed in July and August, which are the months in which food availability is supposed to be the greatest since grains have just been harvested. Food consumption data were evaluated using the food consumption score (FCS) indicator (World Food Program, 2009). FCS was used as a proxy of the dietary diversity, energy and macro/micro (content) value of the food that people eat. The FCS is calculated from the types of foods and the frequencies with which they are consumed during a seven-day period. Each food group is assigned a weight on a scale from 0.5 to 4 , reflecting its nutrient density. Food types considered and related weights included: cereals and tubers (2), pulses (3), vegetables (1), fruits (1), meat and fish (4), milk (4), sugar $(0.5)$ and oils (0.5). Households were asked to recall the food types that they consumed in the previous seven days. Each item was given a score of 0 to 7, depending on the number of days on which it was consumed. Any summed food group frequency value over 7 was recoded as 7 . The household FCS was calculated by multiplying each food group frequency by each food group weight and then summing these scores into one composite score. The household score can have a maximum value of 112, implying that each of food group was consumed every day for the previous seven days. The household score was compared with the following pre-established thresholds that indicate the status of the household's food consumption: poor food consumption (0 to 21), borderline food consumption (21.5 to 35), and acceptable food consumption ( $>35)$.

Since basic food is based on cereals, a basic carbohydrate sufficiency threshold was based on cereals production of the families. A theoretical self-sufficiency threshold was obtained by dividing the amount of millet, sorghum, rice and maize produced by the number of days and people in the family.

Family wealth was classified into three classes (high, medium and low) on the basis of the following set of indicators: income (meticais/year), number of persons per family (mean), number of cultivated plots (machambas), cultivation of vegetables, cultivation of high-value cash crops, employment and payment of temporary workers. 
Families' water access was evaluated on a three-levels scale (good, poor, scarce) using the following indicators: water source type (modern well, river, traditional well), water consumption (liters per day) and walking distance (hours) from the house to the water source.

\subsection{The Interviews to the traditional Authorities}

At least one traditional authority per regulado was interviewed. All interviewed authorities were male; in total 26 interviews (8 Regulo, 14 Saphanda, 4 N'fumo) were collected. Authorities, whose mean age was 57, were not able to speak portoguese since most of the regulos did not go to school education or completed only the third class.

Questions provided to the traditional authorities tackled three themes: the mechanisms of land access for the families, authorities' knowledge of the Land Law and the flow of information, within and outside the communities. In particular, authorities were asked for details about how land is requested and assigned, the source and nature of disputes in the neighbourhood about land, whether and how those were resolved and which parties were involved. The analyses of the data collected in the interviews to key informants were not subject to quantitative statistical treatment given the low number of interviews.

\section{Results}

\subsection{Livelihood Strategies}

The analysis of the rural families' livelihoods in the district of Caia revealed a complicated and delicate risk management system built on different sources of income and spanning over a wide territory that allows families to survive in critical times. Each family works on two or more machambas (median of 3 ha; mean of 3.8 ha per family, maximum of 6), usually fragmented in different locations. Diversifying machamba locations is a strategy that families adopt to respond to low and unevenly distributed rainfall. One machamba is set close to the house, between 5 and 30 minutes walking distance from the houses, the others are located around one hour away with some up to 2 hours or more from the houses, in the lowlands (baixa). Fields set in the lowlands tolerate periods of drought because they collect all the water available in the watershed. The baixa produces about twice as much food as the rain-fed machamba. In the lowlands families are able to grow cash crops, including vegetables, sugar cane, and rice. In the rainy season, the lower machamba is completely flooded but the higher machamba keeps producing. Basic foods in all families are sorghum or millet porridge. Taking into consideration the sole cereal quantities available to the families, assuming for all the family members the same quantities and a daily necessity of $0.5 \mathrm{~kg} /$ cereals/person, $51 \%$ of the families cannot guarantee adequate food consumption. FCS scores for the families are shown in Table 2. Results indicate that most people's food consumption is considered "borderline" according to international standards. Mozambique is below the recommended minimum daily calories intake of 2100 per person $(1919 \mathrm{cal})$ and falls below the recommended minimum daily proteins intake of $52 \mathrm{~g}$ per person $(38 \mathrm{~g})$.

Table 2. Food consumption scores

\begin{tabular}{lll}
\hline Families (\%) & FCS score & Description \\
\hline 11 & $<21$ & poor food consumption \\
66 & $<21.5$ and $<35$ & borderline food consumption \\
23 & $>35$ & acceptable food consumption \\
\hline
\end{tabular}

Remarkably, a sort of fatalism emerged in all the interviews, a mix of pride and resignation as proven by the statement: "From hunger it is not possible to escape". Indeed, since a successful harvest basically depends on chance (i.e. on rains availability and lack of locusts' attacks) and successful risk management strategies, no one can assure people that they will have greater chances or a better land in another location. Of the families interviewed, $76 \%$ declare that they have completely lost a harvest at least once. The main causes of harvest loss are drought $(86 \%)$ and locust invasions $(72 \%)$. Maintaining different machamba locations is also a strategy against unpredictable locust swarm random attacks. Families carefully decide how to distribute investments among the attainable possibilities to face the uncertainty inherent in subsistence production (i.e. crop failure, drought, locusts, etc). Families face the choice between investing more or less labour in soils that will yield bumper crops under optimum conditions and sowing drought soils that assure production, but do not yield in quantity. Basic widespread cultivated crops are sorghum, millet and maize; millet is a drought resistant crop 
while sorghum provides greater yields. Sorghum does not suffer drought periods but birds heavily affect it.

The wealthy families have more than two spatially distributed machambas with crops allocated proportionally. In these families, men have their own machamba where more than 5 seasonal workers are usually employed to cultivate high value crops (i.e. not directly used by the family) that are primarily intended for sale (Table 3 ). The wives cultivate their machambas associating maize and sorghum. An additional smaller machamba is cultivated with vegetables for the family subsistence. A total production equivalent to 20-30.000 meticais/year is still well below the international poverty line, but nevertheless sufficient to meet basic needs.

Table 3. High value crops, primarily intended for sale, cultivated by the farmers in Caia district

\begin{tabular}{lll}
\hline $\begin{array}{l}\text { Proportion of families growing the } \\
\text { high value crop (\%) }\end{array}$ & High value crop & $\begin{array}{l}\text { Market price } \\
(1 \text { metical }=0.0363 \text { US\$) }\end{array}$ \\
\hline 89 & Sesame & 20 meticais $/ \mathrm{kg}$ \\
18 & Cotton & 6 meticais $/ \mathrm{kg}$ \\
21 & Peanuts & 15 meticais $/ \mathrm{kg}$ \\
\hline
\end{tabular}

Medium income families cultivate sesame and maize together, and an additional machamba is left for sorghum (or sorghum/millet) and/or for cotton. The poorest families cultivate only subsistence crops, i.e. sorghum and maize. Adopting this rationale for classification, the vast majority of the families fall in the lowest class of subsistence livelihood $(70 \%)$ while only $11 \%$ of the families live in relatively wealthier conditions and the remainder $19 \%$ bears an intermediate status.

Migration is a strategy adopted during difficult periods. 35\% of the interviewed families migrated from other villages, either from other parts of the district of Caia or from contiguous districts, looking for water sources and fertile land. People in the interior declared that they came looking for new machambas; in the corridor, people affirmed that they migrated searching for water sources. Of all the visited communities, $25 \%$ were found to have access to a functioning and easily accessible well and 39\% do not have access to a well. The remaining $36 \%$ have a well but it does not meet their needs: half of these wells suffer from salted or polluted water and the other half are difficult to access. In particular, in the interior villages where the problem of water scarcity is particularly severe, women need to walk more than three hours to reach a water source. In the villages close to the corridor, wells do not have sufficient yield capacity to satisfy population needs and people queue for about two or three hours to collect water. Mean consumption per capita in the visited villages is 10 liters per day. Family access to water is shown in Table 4, as a weighted sum of three factors (category of water source, water consumption and water accessibility).

Table 4. Access to water: category of water source, water consumption and water accessibility

\begin{tabular}{|c|c|c|c|c|}
\hline & Water source & $\begin{array}{l}\text { Daily water usage } \\
\text { per capita }\end{array}$ & $\begin{array}{l}\text { Walking distance to } \\
\text { water source }\end{array}$ & Families (\%) \\
\hline Good & Functioning well & $>20 \mathrm{~L}$ & $<30$ minutes walking & 56 \\
\hline Poor & River and lagoon & $10-20 \mathrm{~L}$ & $>30$ minutes and $<1$ hour & 25 \\
\hline Scarce & $\begin{array}{l}\text { Traditional well } \\
\text { (high acquifer) }\end{array}$ & $<10$ & $>1$ hour & 19 \\
\hline
\end{tabular}

With respect to gathering wood, $80 \%$ of the families living in the interior collect wood in the machamba or in the vicinity of the house. All the families living in the villages close to the corridor walk three to four hours to a harvestable forest since nearer forests have been overexploited.

Sesame is sold directly to freight brokers. Only sorghum, which is rarely sold, and maize are commercialized directly in the farmers market in Sena. All families that cultivate cotton sell it directly in the field to the CAN (Companhia Algodeira Nacional) of Sena that fixes the price of cotton and provides farmers with seeds and chemical treatments. Farmers also receive technical assistance from the factory with consultants periodically visiting the fields. Only $10 \%$ of the families interviewed receive technical assistance from the government 
district consultants, both in agricultural activities and in cattle breeding.

\subsection{Land Access}

All older authorities ( $>$ than 40 years old) have three or more wives (the maximum found was 7 ), a number that is above the average value: in fact one or two wives compose $86 \%$ of the families.

None of the authorities have been elected; they inherited the position. Only two are authority "of trust", that means chosen by their regulo because of their knowledge, wisdom or correct conduct. All the visited aldeias were created in the colonial era. The problems that the authorities face in their community are mostly familiar, that means problems related to alcohol abuse and marital distresses. The hierarchic structure-Regulo, Saphanda, N'fumo-is always respected in information transmission and in decision-making.

Authorities have personal counsellors. Moreover, comprehensive councils meet once or twice a month; ten to twenty persons form them and they meet assess the community "behaviour". They also have administrative tasks, like the transmission of information from the municipalities of Caia and Sena to the rural population.

The talhao, the land plot on which people build their house, is given to the youngsters when they marry and they form a new family. The only responsible for the decision is the father that assigns a land to the son and then informs the authority of the decision taken. Only in the regulados that include the settlements close to the corridor the dimension of the talhao depends on the composition of the family. Not surprisingly, these are the regulados that are experiencing immigration from people looking for land. In the regulados in the interior part of the district land abundance is not a problem hence the regulo does not intervene in the decision. When a land is disputed, the authority_looks for "signs" that could indicate who the legitimate "owner" of the land is.

There are only two forest concessionaires in the district. Consultations for the DUAT were performed in one meeting only and attended by community leaders (traditional chiefs, local party leaders) and a limited number of 'community representatives'; it was not clear whether and how those people really represented the community in question. The boundaries of the concession request were indicated on maps or in conversation but never verified (walked) during the consultation. Authorities completely ignore the rights the land law assures to local communities when negotiating with timber companies. The M'fumo Reici Gino stated the meeting with the community, in 2007, ended with the promise of a new school, never fulfilled. No document was signed between the concessionaire and the community. All registered "negotiations" ended with short-term returns, often personal for the Regulo and the participants to the meeting. The authority Saphanda Kofe complained that the timber industry sometimes enters in his regulado and cuts trees: "They gave us things to do the ceremony and they left". The Regulo of Chatala declared that the concession of the timber industry within is regulado is 50 ha; actually it is about 2500 ha.

Despite being the majority of the workforce in rural lands, women were not involved in the consultation processes. Provisions of consultation records concerning benefit-sharing, time-bound targets or measurable indicators of progress could not be found, nor do proposed or effective sanctions exist in case of non-compliance of the concession. In practice, several agreements between communities and investors involved one-shot decision with few people from the community that accepted very small payments (a grain mill, a local shop) compared to the value of the forest concessions "acquired" by the investor.

\section{Discussion and Conclusions}

The first assumption I explored is that investors acquire the use of marginal or unused lands that in this way increase their productivity and utility. This study showed that in the district of Caia what is superficially considered by the government_unused and marginal lands is in fact the land that allows people to sustain their complex livelihoods. Rural people have developed a complex system of life risk-management that requires a wide territory to sustain a subsistence economy. At territorial scale, the results did not identify clusters of poverty or wealth. In the Caia district, successful livelihood strategies highly depend on families' personal strategies to cope with risk.

Consistent with the government analysis, this research did show that in the inner part of the district there is a lack of or an insufficient access to basic infrastructures such as roads and water wells. Migration flows caused by environmental drivers are clearly emerging, as described in section 5.1. As expected, people displace in search of water from the inner areas towards the corridor; in some areas of the interior of the district, in fact, women need more than three hours to reach a water source. This study highlighted an emerging migration flow: people return to the mato in search of new machamba to cultivate. As a consequence of new people migrating from the interior, access to resources in the corridor (water, land and fuel) is becoming difficult. Women walk for four hours to reach the forest to get wood, queuing time at the water wells is on average one hour, and fertile machamba are 
becoming scarce. It is strongly recommended that access to natural resources should be an absolute priority for the land planning policy in the area; the objective of reallocation of people in the corridor to assure them a better life will fail completely if it won't be coupled with projects of forest restoration and water sources protection.

The second assumption is that the mandatory community consultation process established by the 1997 Land Law paves the way for investors' access to land while protecting local land rights and improving life conditions. The research described the mechanisms of land access of the rural communities of the district of Caia and found that are all based on customary law. This study showed that the communities are totally unprepared to negotiate with emerging land investors since awareness of their rights under the land law is very weak. Much of the Regulos do not know the Land Law because till now land was more than enough for everyone in the mato. Shortcomings in the design and implementation of the community consultation process have been reported in the literature (Durang \& Tanner, 2004; Johnstone et al., 2004; Norfolk \& Tanner, 2007; Chilundo et al., 2005) and the results do not indicate a better situation. Hanlon (2002) claims that so far communities do not understand the value and potential of their land. In the district of Caia, communities which have been 'consulted' and come to an agreement often have no understanding that they are giving up this land permanently, and they have no understanding of the value of what they are giving away. The actual "negotiation model" is a new trap for local communities that receive a grain mill for many hectares of their land. There is a very modest history of state-encouraged open 'consultation' or 'participatory' democratic engagement in rural Mozambique, while the dominant model is a command hierarchy. If the explicit purpose of law is to protect and serve local communities, this does not seem to be the path to achieve that.

The livelihood analysis coupled with the qualitative analysis carried out with the authorities put in evidence that the dispersed setting of the hamlets is not the cause of poverty, but on the contrary the pattern of families' livelihoods that allows them to survive. Moving people from the "wide" territory will not remove the main obstacles to development as claimed by the government. The results show that the current policy is not addressing the real causes of poverty. The actual constraints that the people living in the rural areas are facing: insufficient access to basic infrastructures and insufficient information and support by local authorities. Farmers in the interior seem to have been abandoned by local authorities, not only because they are not intervening in the land deals negotiations: evidences are based on the concrete difficulty to access urban markets, the relations between producers and traders and farmers' (dis)information on how markets operate, including price fluctuations.

Access to urban markets is crucial to increase incomes for rural and peri-urban producers: although the entire inner district commerce gravitates around the city of Sena, the road network to reach the interior is in very poor conditions and roads become impassable in the rain season. The relationship between producers and traders, in particular in the cotton sector, has not changed significantly, even since colonial times. As in the 1930s, during the monopolistic regime of the CAN (Isaacman et al., 1980) the factory imposed prices outside market rules. The price of cotton has drastically dropped in the last years and is currently around 5-6 meticais $/ \mathrm{kg}$. As a consequence, many farmers abandoned the cultivation of cotton and shifted to growing sesame that is sold at 20 meticais $/ \mathrm{kg}$. The cost of agricultural products is directly proportional to their energy intake from the soil (Dorigatti 2009, int.) and the market considers sesame as a high nutrients uptake. This means that sesame cultivation is highly rentable because theoretically these returns can last few years due to the rapid depletion of soil fertility. The situation deserves particular attention from agricultural authorities. Sorghum, the crop that the mayority of the families has decided to cultivate, is taking a lot of energy from the soil and Caia farmers may soon face a long-term crisis caused by soil fertility decrease due to thoughtless short-term decisions.

Farmers are totally vulnerable since they are not making informed decisions on what to cultivate, how to cope with climate variability, or how to choose products based on market price fluctuations. These results are relevant in the evolving context of large-scale land investments. Unless the negotiating position of smallholders in market relations is improved concurrently with access to required technical expertise and inputs, and enhancement of land and natural resources for agricultural and off-farm activities, increased market interaction and commercialization can actually lock people into unreliable short-term survival type strategies at the expense of long-term livelihood security and response capacity. Even if accurate data on land concessions are not available due to their political sensitivity, the fact that policy is not addressing the consequences of land acquisitions in the inner part of the district is becoming increasingly evident. The actual "negotiation model" emphasises one-off compensations for loss of land rights rather than long-term benefit sharing. Consultation nowadays is really just (under)selling land. As consultations are considered by the State land administration to be the key and sufficient mechanism for protecting land rights, the reality is worrying. Protecting existing rights in practice and making them work in favour of an equitable and sustainable model of development remains a challenge and takes on 
new urgency, as demand for land by investors continues to rise.

\section{References}

Chilundo, A., Cau, B., Mubia, M., Malauene, D., \& Muchanga, V. (2005). Land Registration in Nampula and Zambezia Provinces, Mozambique. Maputo: International Institute for Environment and Development.

Cotula, L., Vermeulen, S., Leonard, R., \& Keeley, J. (2009). Land grab or development opportunity? Agricultural investment and international land deals in Africa. London/Rome: IIED/FAO/IFAD, 2009.

Diamantini, C., Geneletti, D., \& Nicchia, R. (2011). Promoting urban cohesion through town planning. The case of Caia, Mozambique. International Development Planning Review, 33, 179-186. http://dx.doi.org/10.3828/idpr.2011.7

Dorigatti, L. (2009). Agricultural consultant. Caia, 18082009.

Durang, T., \& Tanner, C. (2004). Access to land and other natural resources for local communities in Mozambique: Current Examples from Manica Province. Green Agri Net Conference on 'Land Registration in Practice', Denmark.

Food and Agriculture Organization. (2008). The state of food and agriculture. Biofuels: prospects, risks and opportunities. Rome: Food and Agriculture Organization.

Governo do Distrito de Caia. (2006). PEDD - Plano Estratégico de Desenvolvimento, Caia.

Hallam, D. (2009). Foreign investment in developing country agriculture-issues, policy implications and international response. Paper Presented at the OECD Global Forum on International Investment VIII 7-8 December 2009.

Hanlon, J. (2002). The land debate in Mozambique: will foreign investors, the urban elite, advanced peasants or family farmers drive rural development? London: Oxfam GB - Regional Management Center for Southern Africa.

Haralambous, S., Liversage, H., \& Romano, M. (2009). The growing demand for land. Risks and opportunities for smallholder farmers. Rome: International Fund for Agricultural Development.

Isaacman, A., Stephen, M., Adam, Y., Homen, M. J., Macamo, E., \& Pililao, A. (1980). "Cotton Is the Mother of Poverty": Peasant Resistance to Forced Cotton Production in Mozambique, 1938-1961. The International Journal of African Historical Studies, 13, 581- 615. http://dx.doi.org/10.2307/218197

Johnstone, R., Baoventura, C., \& Norfolk, S. (2004). Forestry Legislation in Mozambique: Compliance and the Impact on Forest Communities. Maputo: Terra Firma Lda.

Kugelman M., \& Levenstein, S. L. (2009). Land grab? The race for the world's farmland. Washington: Woodrow Wilson International Center for Scholars.

Nhantumbo, I., \& Salomao, A. (2009). Biofuels, Land Access and Rural Livelihoods in Mozambique. Maputo: Centro Terra Viva.

Norfolk, S., \& Tanner, C. (2007). Improving tenure security for the rural poor. Mozambique country case study. Rome: Food and Agriculture Organization.

Robertson, B., \& Pinstrup-Andersen, P. (2010). Global land acquisition: neo-colonialism or development opportunity? Food Security, 2, 271-283. http://dx.doi.org/10.1007/s12571-010-0068-1

Sansom, B. (1974). Traditional economic systems. in Hammond-Tooke H. (ed.), The Bantu-speaking peoples if southern Africa. London: Routledge and Kegan Paul.

Smaller, C., \& Mann, H. (2009). A Thirst for Distant Lands Foreign investment in agricultural land and water. Winnipeg: International Institute for Sustainable Development.

Taylor, M., \& Bending, T. (2009). Increasing commercial pressure on land: building a coordinated response. Rome: International Land Coalition.

von Braun, J., \& Meinzen-Dick, R. (2009) Land grabbing” by foreign investors in developing countries: risks and opportunities. Washington D.C.: International Food Policy Research Institute.

World Food Program. (2009). Emergency Food Security Assessment Handbook. Rome: World Food Program. 